\title{
Investigation of Pre-service Teachers' Techno-pedagogical Skills and Lifelong Learning Tendencies
}

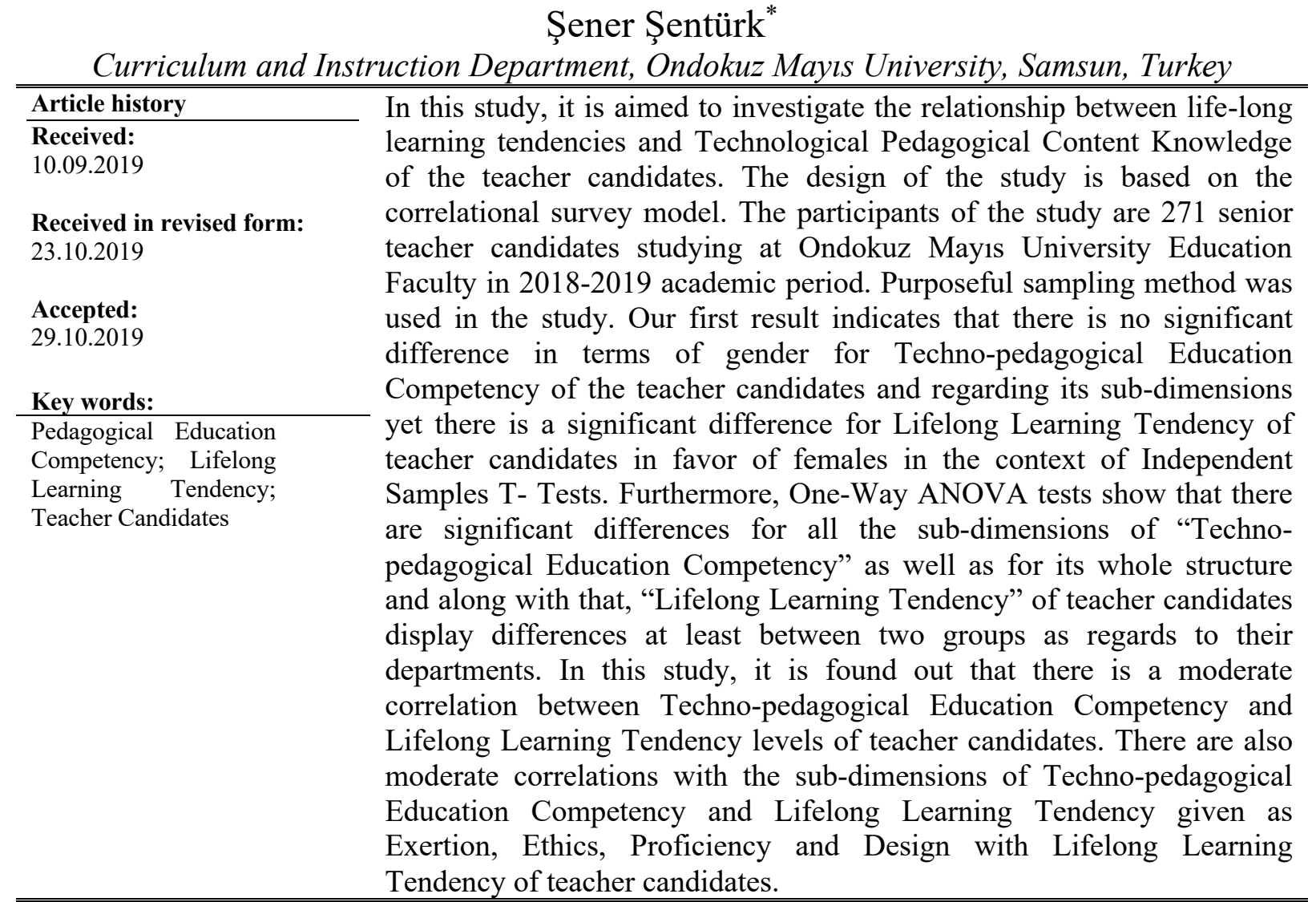

\section{Introduction}

The developments in science and technology have introduced major innovations and perspectives to education and to many other disciplines. Technological support for education is increasing, and thus technology-based learning and teaching systems have emerged in a quick fashion. To that end it would be fair to state that many new competencies as well as novel skills are required for teachers and educators in order to adapt themselves into this everchanging system (Murat and Erten, 2018: 62). Bearing in mind the significant position that science and technology have in the education process, educators should incorporate technology in their lessons to better teach their learners. It can be indicated that the technological abilities of educators include not only computer and web-based expertise, abilities and behaviors, but also the capacity to add various IT and interaction techniques onto 
the learning system (Horzum, 2011). In this respect, it is not enough for teachers to use technology only by following technological developments; but it becomes necessary to make use of technology fully when organizing learning activities (Akpınar, 2003). Effective incorporation of those skills includes factors such as teaching and curriculum, teaching skills, long-term financing, institutional readiness and life-long learning skills (Tinio 2003). Lifelong learning cannot be considered as an activity that contributes only to the professional careers of individuals and hence it should not be limited only to the framework of childhood and youth education. It indeed is a much wider process encompassing every period of an individual's life (Gündoğan, 2003). Furthermore, the contemporary educational system continues to be strongly frontloaded, with a strong emphasis on the childhood and teenage period of life. Therefore, current educational system often seemingly discourages the involvement of adults in life-long learning activities and it also cannot respond to the requirements for such a longterm education at a desired level. Thus, lifelong learning gains importance in this respect. It is seen as an unavoidable need for individuals and especially for teachers to personally develop so that they can meet the changing quality requirements and adjust themselves to professional life (Bilir, 2006). Here life-long learning tendencies are of significance for every teacher or teacher candidate in order to be able to meet the dynamic changes of technological and social developments.

IT (information technology) is the foundation for the teaching and education setting and helps people to pursue the professional schooling of culture as a whole, develop their understanding and possibilities, acquire fresh skills in their careers and pick up employment possibilities for coastal distant regions (Murat, Erten, 2018: 62). Öztürk (2013) emphasizes that it is the educator's duty to choose suitable equipment for learners in academic organizations to create efficient use of technology. It is evident that educators need the required expertise to incorporate information technologies in school teaching with an emphasis on the promotion of understanding by learners in order for these policies to succeed (Chai, Koh \& Tsai 2011: 595). Therefore, one of the important competencies related with the IT and technological skills is Technological Pedagogical Content Knowledge. Before examining the Technological Pedagogical Content Knowledge, it is also important to mention pedagogical knowledge. The main focus has always been on the content knowledge of the teachers until the end of 1980s (Shulman, 1986). In Shulman's 1987 study, pedagogical content knowledge was integrated into the pedagogical knowledge, forming the integrated structure of teacher knowledge. This framework showed a competency that encloses the relationship between the content knowledge of educators and their pedagogical expertise. Technological pedagogical content knowledge developed over the previous years was centred on the notion that technology should also be included in this competency (Horzum, 2011).

Technological Pedagogical Content Knowledge (TPACK) is basically defined as a framework of teacher knowledge for technology integration. The three main components of teacher knowledge in the TPACK framework are Content Knowledge (CK), Pedagogical Knowledge (PK) and Technological Knowledge (TK) as seen in Figure 1. According to Kabakç1 Yurdakul et all. (2012), there are four factors for Technological Pedagogical Content Knowledge shared as: Design, Exertion, Ethics and Profession. The design dimension covers the development of courses, teaching and learning environments and the mixture of appropriate technological equipment, tools and learning tools. The exertion element is related to the implementation of designed plans and the facilitation is possible with the use of appropriate technologies through carrying out efficient tests and evaluations. Ethics dimension is related to both technological ethics and personal problems. The proficiency 
dimension is linked to improved and efficient use of technical assets by incorporating the technology into the educating and learning system (Kabakçı Yurdakul et all. 2012).

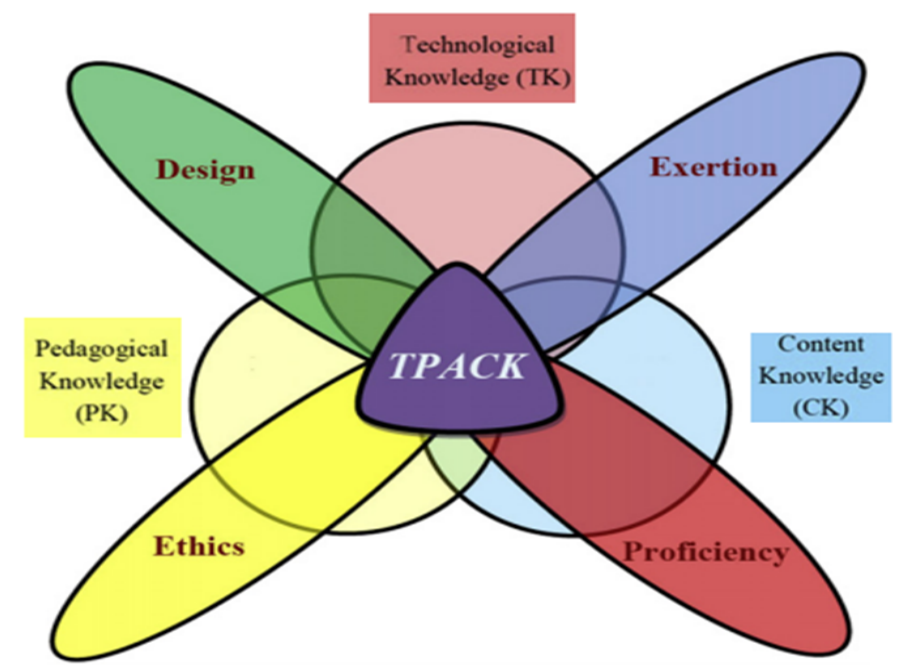

Figure 1. The framework and factors of TPACK-deep scale (Kabakçı Yurdakul et all. 2012).

To summarize, Technological Pedagogical Content Knowledge can be regarded as an important skill for teachers to enhance their readiness for current demands of social and technological requirements. However, it is thought that life-long learning tendencies play a fundamental role in achieving this. Therefore, in this study, it is aimed to investigate the relationship between life-long learning tendencies and Technological Pedagogical Content Knowledge of the teacher candidates. The following questions are sought in this manner for this study:

- Do "Techno Pedagogical Education Competency" and "Lifelong Learning Tendency" of teacher candidates differ in terms of gender?

- Do "Techno Pedagogical Education Competency" and "Lifelong Learning Tendency" of teacher candidates differ in terms of departments?

- Is there any significant correlation among "Techno Pedagogical Education Competency" as well as its sub-dimensions and "Lifelong Learning Tendency" of teacher candidates?

\section{METHOD}

\subsection{Model of the Research}

The design of the study is based on the correlational survey model. Survey designs include techniques of studies aimed at describing an existing or previous condition. The correlational survey model is a type of research model for studies which seek to determine whether two or more factors are related to the degree of the connection between these factors. Relationships between factors can be investigated in correlational survey designs in two ways as correlational-type relational survey model and as comparison type relational survey model. Correlation-type relational survey model tries to determine whether the variables change together or not. In the comparison type relational survey model, there are at least two variables and groups are formed according to one of them (independent variable) and it is 
examined whether there is a change between them with respect to the other variable (dependent variable) (Johnson and Christensen, 2014; Karasar, 2009).

\subsection{Study Group}

The participants of the study are 271 senior teacher candidates studying at Ondokuz Mayis University Education Faculty in 2018-2019 academic year. Purposeful sampling is a method used extensively in qualitative research to identify and select instances which are rich in terms of information for the most efficient spending of restricted funds (Patton, 2002; Palinkas et all. 2015). In other words, purposeful sampling requires access to key informants in the field who can help in identifying information-rich cases (Suri, 2011). Therefore, people or organizations who are particularly aware of or have experiences with an interesting phenomenon are identified and selected accordingly (Cresswell and Plano Clark 2011; Palinkas et all. 2015). Hence, in this study, the sample was chosen based on the criteria for identification and selection.

The first criterion is that the sample should be chosen within education faculty and a second criterion is that the sample should be among $4^{\text {th }}$ grade students. The distribution of the students according to their departments shows that the highest number of students are situated in Special Education Department.

Table 3. 1. The distribution of the students according to the departments of the students.

\begin{tabular}{lc}
\hline Department & N \\
\hline Primary School Teaching & 26 \\
Pre-school Teaching & 12 \\
Foreign Language Teaching & 37 \\
Mathematics Teaching & 32 \\
Social Sciences Teaching & 29 \\
Psychological Guidance and Counselling & 13 \\
Turkish Teaching & 20 \\
Special Education & 102 \\
Total & 271 \\
\hline
\end{tabular}

- In relational screening studies the following formula will be used to determine the sample size (Tabachnick and Fidell, 2007):

- $\quad \mathrm{N}>50+8 \mathrm{~m}$

- $\mathrm{N}$ : individual number m: number of independent variables

In the study, the independent variables were as follows: two independent gender variables, 7 independent variables for the department, the formula was calculated again for 9 independent variables; $50+8.9=122$ which is considered necessary for the quantitative dimension of this study. It could be articulated that the sample of this study is convenient for survey design.

\subsection{Data Collection Tools}

Techno-pedagogical Education Competency Scale developed by Kabakçı Yurdakul, I., Odabas1, Kılıçer, Çoklar, Birinci and Kurt, (2012) and the Lifelong Learning Tendency Scale developed by Yaman (2014) were used to collect the research data. 


\subsubsection{Techno-pedagogical Education Competency Scale}

Techno-pedagogical Education Competency Scale (TPACK-deep) - consists of 33 items and four factors. These factors are; design, exertion, ethics and proficiency. The scale items are 5point Likert type given as "I can do it easily", "I can", "I can partially", I can't" and "I absolutely can't". The internal consistency coefficient (Cronbach's alpha coefficient) for the whole scale was found to be .95 . The internal consistency coefficient (Cronbach's alpha coefficient) of the factors constituting the scale is between .85 and .92 . At the same time, a four-factor structure was confirmed by confirmatory factor analysis. In addition, the test-retest coefficient of the scale was found to be .80 (Kabakç1 Yurdakul et al., 2012). It can be said that this scale, which is used in the research with these characteristics, is one of the data collection tools that has high validity and reliability among the existing measurement tools found in the literature.

All of the items in the scale are positive expressions and there are no reverse coded items in the scale. The distribution of the items according to the four factors of the scale is as follows:

- Design: Items $1,2,3,4,5,6,7,8,9$ and 10

- Exertion: Items 11, 12, 13, 14, 15, 16, 17,18, 19, 20, 21 and 22

- Ethics: Items 23, 24, 25, 26, 27 and 28

- Proficiency: Items 29, 30, 31, 32 and 33

\subsubsection{Lifelong Learning Tendency Scale}

"Lifelong Learning Tendency Scale" was developed by Yaman (2014). Cronbach alpha coefficient of the "Lifelong Learning Tendency Scale" was found to be 0.91. This scale has 5point Likert type structure having choices as totally agree (5), agree (4), partially agree (3), disagree (2) and totally disagree (1). As a result of the factor analysis, since the items did not form a meaningful integrity and have 12 factors, it was thought that the scale could be evaluated as one-dimensional and it was decided to collect the items under one factor. Therefore, in the analysis the data of this scale was taken as one factor and the sum of all items were taken into consideration.

\subsection{Analysis of the Data}

For the purposes of the research, descriptive statistics such as frequency, standard deviation and mean values were used to determine Techno-pedagogical Education Competency and Lifelong Learning Tendency levels of the teacher candidates. The significance level was taken as 05 in the analysis of the data. In addition, SPSS 17.0 (Statistical Package for the Social Sciences) was used in statistical analysis.

Before conducting the analysis, it is important to determine whether the data is normally distributed or not. After that, one can decide the parametric or non-parametric tests for the analysis of the data. Therefore, the Kolmogorov-Smirnov test and Shapiro-Wilk test were performed to determine the congruity of the distribution of the data. The results show that all the data are not normally distributed. Therefore, non-parametric tests should be performed for the further analysis or the square root transformations can be used for the normalization of the data. In this article, square root transformations were used for the analysis of the data because non-parametric tests are not favourable for the analysis of the data. 
Table 3. 2. Test of normality for all the data

\begin{tabular}{lllll}
\hline Tests of Normality & \multicolumn{2}{l}{ Kolmogorov-Smirnov $^{\mathrm{a}}$} & \multicolumn{2}{c}{ Shapiro-Wilk } \\
\cline { 2 - 5 } & Statistic & Sig. & Statistic & Sig. \\
\hline Techno-pedagogical Education Competency & .142 & .000 & .845 & .000 \\
Lifelong Learning Tendency & .144 & .000 & .877 & .000 \\
Design & .143 & .000 & .837 & .000 \\
Exertion & .121 & .000 & .858 & .000 \\
Ethics & .159 & .000 & .893 & .000 \\
Proficiency & .192 & .000 & .851 & .000 \\
\hline
\end{tabular}

Therefore, Independent Samples T- Test and One-Way ANOVA test were used for the analysis of the data after the normalization of the data through square root transformations.

\section{Findings}

\subsection{Findings regarding the first question "Do 'Techno-pedagogical Education Competency' and 'Lifelong Learning Tendency' of teacher candidates differ in terms of gender?"}

After the normalization of the data through square root transformations, Independent Samples T- Test was performed as a parametric test in order to reveal whether "Techno Pedagogical Education Competency" and "Lifelong Learning Tendency" of teacher candidates differ in terms of gender. The results of Independent Samples T- Test reveal that there is no significant difference in terms of gender for Techno Pedagogical Education Competency of the teacher candidates and its sub-dimensions but there is a significant difference for Lifelong Learning Tendency of teacher candidates given in Table 3.4 in favor of females where their mean value is 124.86 but the mean ranks of the males is 119.57 .

Table 3. 4. Independent Samples T- Test for gender variable at the significance level 0.05

\begin{tabular}{|c|c|c|c|c|c|c|}
\hline & & $\mathrm{F}$ & Sig. & $\mathrm{t}$ & $\mathrm{df}$ & Sig. (2-tailed) \\
\hline \multirow[t]{2}{*}{ Design } & Equal variance assumed & 4.651 & .032 & .290 & 276 & .772 \\
\hline & Equal variances not assumed & & & .306 & 272.064 & .760 \\
\hline \multirow[t]{2}{*}{ Exertion } & Equal variance assumed & 1.478 & .225 & .304 & 274 & .761 \\
\hline & Equal variances not assumed & & & .316 & 273.908 & .752 \\
\hline \multirow[t]{2}{*}{ Ethics } & Equal variance assumed & .663 & .416 & .927 & 276 & .355 \\
\hline & Equal variances not assumed & & & .945 & 271.078 & .346 \\
\hline \multirow[t]{2}{*}{ Proficiency } & Equal variance assumed & 2.392 & .123 & .104 & 276 & .918 \\
\hline & Equal variances not assumed & & & .107 & 274.893 & .915 \\
\hline \multirow[t]{2}{*}{ Teytotal } & Equal variance assumed & 3.349 & .068 & .435 & 274 & .664 \\
\hline & Equal variances not assumed & & & .455 & 273.155 & .650 \\
\hline \multirow[t]{2}{*}{ Bit } & Equal variance assumed & 4.997 & .026 & 2.552 & 268 & .011 \\
\hline & Equal variances not assumed & & & 2.497 & 226.548 & .013 \\
\hline
\end{tabular}

$* \mathrm{p}<0.05$

Table 3.4 indicates that Techno-pedagogical Education Competency of the teacher candidates is independent from their gender implying that gender does not play a role for achieving this perceived competency at all. However, Lifelong Learning Tendency seems to be related with gender and the Lifelong Learning Tendency levels perceived by females are higher than the males implying that females see themselves more inclined to learning and experiencing with 
novel things and topics than males. This might be explained with the fact that the opportunities to access lifelong learning for both gender groups were not quite equal (Chang, $\mathrm{Wu}$ and Lin, 2012) and; therefore, women are more eager to participate in such kinds of activities.

\subsection{Findings regarding the second question "Do 'Techno-pedagogical Education Competency' and 'Lifelong Learning Tendency' of teacher candidates differ in terms of departments?"}

After the normalization of the data through square root transformations, One Way ANOVA was performed in order to reveal whether "Techno Pedagogical Education Competency" and "Lifelong Learning Tendency" of teacher candidates differ in terms of departments. One-Way ANOVA tests show in Table 3.5. that there are significant differences for all the subdimensions of "Techno pedagogical Education Competency" as well as for its whole structure and along with that, "Lifelong Learning Tendency" of teacher candidates display differences as for at least between two groups as regards to their departments.

Table 3. 5. ANOVA test in terms of teacher candidates' departments at the significance level 0.05

\begin{tabular}{|c|c|c|c|c|c|c|c|}
\hline ANOVA & & $\begin{array}{l}\text { Sum of } \\
\text { Squares }\end{array}$ & $\mathrm{df}$ & $\begin{array}{l}\text { Mean } \\
\text { Square }\end{array}$ & $\mathrm{F}$ & Sig. & $\begin{array}{l}\text { Difference } \\
\text { Table** }\end{array}$ \\
\hline \multirow[t]{3}{*}{ Design } & Between Groups & 2192.743 & 7 & 313.249 & \multirow[t]{3}{*}{5.802} & \multirow[t]{3}{*}{.000} & $3<5, \quad 3<6$, \\
\hline & Within Groups & 14630.999 & 271 & 53,989 & & & $4<5, \quad 4<6$, \\
\hline & Total & 16823.742 & 278 & & & & $\begin{array}{l}4<8, \quad 5>7, \\
6>7, \quad 7<8 .\end{array}$ \\
\hline \multirow[t]{3}{*}{ Exertion } & Between Groups & 3026.514 & 7 & 432.359 & \multirow[t]{3}{*}{6.000} & \multirow[t]{3}{*}{.000} & $3<5, \quad 3<6$, \\
\hline & Within Groups & 19384.966 & 269 & 72.063 & & & $4<5,4<6$ \\
\hline & Total & 22411.480 & 276 & & & & $5>7,6>7$ \\
\hline \multirow[t]{3}{*}{ Ethics } & Between Groups & 549.793 & 7 & 78.542 & \multirow[t]{3}{*}{3.383} & \multirow[t]{3}{*}{.002} & \multirow[t]{3}{*}{$4<5,5>7$} \\
\hline & Within Groups & 6291.884 & 271 & 23.217 & & & \\
\hline & Total & 6841.677 & 278 & & & & \\
\hline \multirow[t]{3}{*}{ Proficiency } & Between Groups & 340.436 & 7 & 48.634 & \multirow[t]{3}{*}{3.061} & \multirow[t]{3}{*}{.004} & \multirow[t]{3}{*}{$5>7,7<8$} \\
\hline & Within Groups & 4306.217 & 271 & 15.890 & & & \\
\hline & Total & 4646.652 & 278 & & & & \\
\hline \multirow[t]{3}{*}{ Teytotal } & Between Groups & 19895.376 & 7 & 2842.197 & \multirow[t]{3}{*}{5.518} & \multirow[t]{3}{*}{.000} & \multirow{3}{*}{$\begin{array}{l}3<5, \quad 4<5, \\
4<6, \quad 5>7, \\
6>7, \quad 7<8\end{array}$} \\
\hline & Within Groups & 138547.693 & 269 & 515.047 & & & \\
\hline & Total & 158443.069 & 276 & & & & \\
\hline \multirow[t]{3}{*}{ Bit } & Between Groups & 10405.216 & 7 & 1486.459 & \multirow[t]{3}{*}{5.752} & \multirow[t]{3}{*}{.000} & \multirow{3}{*}{$\begin{array}{l}1<5, \quad 3>4, \\
3>7, \quad 4<5, \\
5>7,6>7,\end{array}$} \\
\hline & Within Groups & 67970.873 & 263 & 258.444 & & & \\
\hline & Total & 78376.089 & 270 & & & & \\
\hline
\end{tabular}

$* \mathrm{p}<0.05 * *$ Codes; $1=$ Primary School Teaching, 2= Pre-school Teaching, 3= Foreign Language Teaching, 4= Mathematics Teaching, 5= Social Sciences Teaching, 6= Psychological Guidance and Counselling, 7= Turkish Teaching, $8=$ Special Education

One-way analysis of variance (Anova) was used to determine whether the mean scores of techno-pedagogical competence and lifelong learning tendencies of the prospective teachers showed a significant difference according to the department (Anova) in terms of Technopedagogical competence $(\mathrm{F}=5,518 ; \mathrm{p}=0,000<0.05)$ and lifelong learning tendencies $(\mathrm{F}=$ $5.752 ; \mathrm{p}=0.000<0.05)$. Complementary post-hoc analysis was performed to determine the sources of differences. In terms of Techno-pedagogical Education Competency, Psychological Guidance and Counseling Department scores $(148.385 \pm 8.099)$ and Social Sciences Teaching Department scores $(145.897 \pm 12.608)$ were higher than those of the other 
departments. In terms of Lifelong Learning Tendency scores, Social Sciences Teaching scores $(132.759 \pm 7.619)$ and Psychological Guidance and Counseling section scores (131.231 \pm 6.166) were higher than the other branches. The details of the significant differences between the departments are given in Table 3.6.

Table 3. 6. Descriptive results for Techno-pedagogical Education Competency and Lifelong Learning Tendency

\begin{tabular}{|c|c|c|c|c|c|c|}
\hline & & & $\mathrm{N}$ & Mean & $\begin{array}{l}\text { Std. } \\
\text { Deviation }\end{array}$ & Std. Error \\
\hline \multirow{9}{*}{$\begin{array}{l}\text { Techno-pedagogical } \\
\text { Education } \\
\text { Competency }\end{array}$} & \multicolumn{2}{|l|}{ 1.Primary School Teaching } & 27 & 129.926 & 24.145 & 4,647 \\
\hline & \multicolumn{2}{|l|}{ 2.Pre-school Teaching } & 13 & 130.308 & 19.926 & 5,527 \\
\hline & \multicolumn{2}{|l|}{ 3.Foreign Language Teaching } & 37 & 127.162 & 36.617 & 6.020 \\
\hline & \multicolumn{2}{|l|}{ 4.Mathematics Teaching } & 35 & 122.200 & 20.732 & 3.504 \\
\hline & \multicolumn{2}{|l|}{ 5.Social Sciences Teaching } & 29 & 145.897 & 12.608 & 2.341 \\
\hline & \multicolumn{2}{|l|}{ 6.Psychological Guidance } & 13 & 148.385 & 8.099 & 2.247 \\
\hline & \multicolumn{2}{|l|}{ 7.Turkish Teaching } & 20 & 118.450 & 26.578 & 5.943 \\
\hline & \multicolumn{2}{|l|}{ 8.Special Education } & 103 & 137.485 & 19.068 & 1.879 \\
\hline & \multicolumn{2}{|l|}{ Total } & 277 & 133.119 & 23.960 & 1.440 \\
\hline \multirow{9}{*}{$\begin{array}{l}\text { Lifelong } \\
\text { Learning } \\
\text { Tendency }\end{array}$} & \multicolumn{2}{|l|}{ 1.Primary School Teaching } & 26 & 117.539 & 21.632 & 4.242 \\
\hline & \multicolumn{2}{|l|}{ 2.Pre-school Teaching } & 12 & 112.583 & 29.543 & 8.528 \\
\hline & \multicolumn{2}{|l|}{ 3.Foreign Language Teaching } & 37 & 128.243 & 12.947 & 2.129 \\
\hline & \multicolumn{2}{|l|}{ 4.Mathematics Teaching } & 32 & 116.344 & 17.511 & 3.095 \\
\hline & \multicolumn{2}{|l|}{ 5.Social Sciences Teaching } & 29 & 132.759 & 7.619 & 1.415 \\
\hline & 6.Psychological Guidance & and & 13 & 131.231 & 6.166 & 1.710 \\
\hline & \multicolumn{2}{|l|}{ 7.Turkish Teaching } & 20 & 112.300 & 19.674 & 4.399 \\
\hline & \multicolumn{2}{|l|}{ 8. Special Education } & 102 & 123.059 & 14.656 & 1.451 \\
\hline & \multicolumn{2}{|l|}{ Total } & 271 & 122.616 & 17.038 & 1.035 \\
\hline
\end{tabular}

Descriptive results for Techno Pedagogical Education Competency indicate that highest score for this competency in general belongs to Psychological Guidance and Counselling and lowest score belongs to Mathematics Teaching Department. As for the Lifelong Learning Tendency, highest score belongs to Psychological Guidance and Counselling and the lowest belongs to Pre-school Teaching and Turkish Teaching (Table 3.6).

Table 3. 7. Descriptive results for the sub-dimensions of the Techno Pedagogical Education Competency at the significance level 0.05

\begin{tabular}{|c|c|c|c|c|c|c|}
\hline & & & $\mathrm{N}$ & Mean & $\begin{array}{l}\text { Std. } \\
\text { Deviation }\end{array}$ & Std. Error \\
\hline \multirow[t]{9}{*}{ Design } & 1.Primary School Teaching & & 27 & 40.519 & 7.485 & 1.441 \\
\hline & 2.Pre-school Teaching & & 13 & 39.769 & 7.014 & 1.945 \\
\hline & 3.Foreign Language Teaching & & 37 & 38.892 & 11.942 & 1.963 \\
\hline & 4.Mathematics Teaching & & 37 & 38.405 & 7.045 & 1.158 \\
\hline & 5.Social Sciences Teaching & & 29 & 45.966 & 3.831 & .711 \\
\hline & $\begin{array}{l}\text { 6.Psychological Guidance } \\
\text { Counselling }\end{array}$ & and & 13 & 46.923 & 3.378 & .937 \\
\hline & 7.Turkish Teaching & & 20 & 37.250 & 8.460 & 1.892 \\
\hline & 8.Special Education & & 103 & 42.893 & 6.068 & .5978 \\
\hline & Total & & 279 & 41.495 & 7.779 & .466 \\
\hline \multirow[t]{9}{*}{ Exertion } & 1.Primary School Teaching & & 27 & 47.333 & 8.426 & 1.621 \\
\hline & 2.Pre-school Teaching & & 13 & 47.000 & 7.746 & 2.148 \\
\hline & 3.Foreign Language Teaching & & 37 & 45.487 & 13.420 & 2.206 \\
\hline & 4.Mathematics Teaching & & 35 & 43.657 & 7.859 & 1.328 \\
\hline & 5.Social Sciences Teaching & & 29 & 53.414 & 4.484 & .833 \\
\hline & $\begin{array}{l}\text { 6.Psychological Guidance } \\
\text { Counselling }\end{array}$ & and & 13 & 54.692 & 3.728 & 1.034 \\
\hline & 7.Turkish Teaching & & 20 & 43.100 & 9.662 & 2.161 \\
\hline & 8.Special Education & & 103 & 49.379 & 7.498 & .739 \\
\hline & Total & & 277 & 48.043 & 9.011 & .541 \\
\hline
\end{tabular}




\begin{tabular}{llllll}
\hline Ethics & & & & \\
\cline { 3 - 5 } & 1.Primary School Teaching & 27 & 22.148 & 5.013 & .965 \\
& 2.Pre-school Teaching & 13 & 23.692 & 4.385 & 1.216 \\
3.Foreign Language Teaching & 37 & 22.838 & 6.530 & 1.074 \\
4.Mathematics Teaching & 37 & 21.081 & 4.763 & .783 \\
5.Social Sciences Teaching & 29 & 24.966 & 3.746 & .696 \\
6.Psychological Guidance & and & 13 & 25.231 & 3.219 & .893 \\
Counselling & & & & \\
& 7.Turkish Teaching & 20 & 20.500 & 5.587 & 1.249 \\
8.Special Education & 103 & 23.942 & 4.368 & .430 \\
Total & 279 & 23.151 & 4.961 & .297 \\
1.Primary School Teaching & 27 & 19.926 & 4.358 & .839 \\
2.Pre-school Teaching & 13 & 19.846 & 4.140 & 1.148 \\
3.Foreign Language Teaching & 37 & 19.946 & 5.995 & .986 \\
4.Mathematics Teaching & 37 & 19.460 & 3.404 & .560 \\
5.Social Sciences Teaching & 29 & 21.552 & 2.707 & .503 \\
6.Psychological Guidance & and & 13 & 21.539 & 2.402 & .666 \\
Counselling & & & & \\
7.Turkish Teaching & 20 & 17.600 & 4.394 & .982 \\
8.Special Education & 103 & 21.272 & 3.507 & .346 \\
Total & 279 & 20.437 & 4.088 & .245 \\
\hline
\end{tabular}

As for the sub-dimensions of the Techno Pedagogical Education Competency, Psychological Guidance and Counselling has the highest score and Turkish Teaching has the lowest score in design dimension. Similarly, Psychological Guidance and Counselling has the highest score and Turkish Teaching has the lowest score in exertion dimension and ethics as well as proficiency dimensions (Table 3.7.).

3.3. Findings regarding the third question "Is there any significant correlation among 'Techno pedagogical Education Competency' as well as its sub-dimensions and 'Lifelong Learning Tendency' of teacher candidates?”

Before the analysis of the correlation results, it would be useful to mention the correspondent levels of different correlation ranges. The correlation constant which is below 0.2 indicates a very weak relationship or the existence of no correlation. The correlation constant which is between 0.2-0.4 indicates poor correlation. The correlation constant between 0.4-0.6 indicates a moderate correlation whereas numbers $0.6-0.8$ indicates a high correlation. The correlation constant above 0.8 indicates a very high correlation.

To that end it is visible that there is a moderate correlation between Techno-pedagogical Education Competency and Lifelong Learning Tendency. Lifelong Learning Tendency also has a moderate correlation with the sub-dimensions as Exertion, Ethics and Proficiency as well as Design as given in Table 3.8.

Table 3. 8.Pearson correlation analysis for the variables at the significance level 0,05.

\begin{tabular}{lllllll}
\hline & Teytotal & Design & Exertion & Ethics & Proficiency \\
\hline BIT & Pearson Correlation & $.458^{* *}$ & $.477^{* *}$ & $.403^{* *}$ & $.410^{* *}$ & $.389^{* *}$ \\
& Sig. (2-tailed) & .000 & .000 & .000 & .000 & .000 \\
& $\mathrm{~N}$ & 270 & 271 & 270 & 271 & 271 \\
\hline
\end{tabular}

$* \mathrm{p}<0.05$

It can be seen that the significant correlations among Techno-pedagogical Education Competency and its sub-dimensions with Lifelong Learning Tendency are at the significance level 0.05 . 


\section{Discussion and Conclusion}

Our first result indicates that there is no significant difference in terms of gender for Techno Pedagogical Education Competency of the teacher candidates and its sub-dimensions but there is a significant difference for Life-Long Learning Tendency of teacher candidates in favour of females. When the literature is examined, it is witnessed that Sezer (2014) also found out no statistically significant difference between genders in terms of TPCK (Technological Pedagogical Content Knowledge) competencies. The finding that perceived TPCK competencies do not differ in relation to gender is a result that is parallel to a fair number of studies' conducted (Akgun, 2013; Jang and Tsai, 2012; Gömleksiz and Fidan, 2011; Kazu and Erten, 2011; İşigüzel, 2014; Kaya, Özdemir, Emre and Kaya, 2011; Koh and Chai, 2011; Murat, 2013; Polat, 2018; Şimşek, Demir, Bağçeci and Kınay, 2013; Ünal Bozcan, 2010). It can be uttered with ease that Techno-pedagogical Education Competency is independent from gender variable. When the literature regarding the relationship between gender and Life-Long Learning Tendencies is examined, it is observed that there are similar findings showing significant difference in favor of females (Coşkun, 2009; Demirel and Akkoyunlu, 2010, Gregg, 1996; İzci and Koç, 2012). It is obvious that gender has an effective role for perceived life-long learning tendencies. Where the rates of different countries are considered, there is a significant gender gap in terms of this (Chang, Wu, Lin, 2012; Mulenga \& Liang, 2008). Similarly, Arulampalam et al. (2004) focused on gender access determinants to life-long learning with respect to differing variables such as fixed term, part-time and fulltime work, public and private sector work, education accomplishments, and the distribution of salaries prior to learning. They discover that women are much more likely to participate in Lifelong trainings than the men in four countries (Spain, Italy, Denmark and Finland). This can be attributed to the fact that generally, women have lesser opportunities in their educational career due to social and cultural expectations (Gunawardena, Rasanayagam, Leitan, Bulumulle, and Dort, 2006; World Bank, 2005, 2007). It seems that women are more eager to be engaged in life-long learning activities than men in our sample in Turkey. Seemingly that women are more likely to participate in lifelong learning activities than men was confirmed by the study of Quintini (2011) and Chłon-Domińczak and Lis (2013) implying that women balance their lack of education by participating in further education, leading to a disappointment in their reduced abilities. This can also reflect the fact that adults from different cultures might view lifelong learning in different ways or might take part in learning activities totally differently and therefore (Chang, Wu and Lin, 2012) gender roles gain significance in such a culture-bound perspective.

One-Way ANOVA tests show that there are significant differences for all the sub-dimensions of "Techno pedagogical Education Competency" as well as for its whole structure and along with that, "Lifelong Learning Tendency" of teacher candidates display differences as for at least between two groups as regards to their departments.

In terms of Techno-pedagogical Education Competency, Psychological Guidance and Counseling Department scores $(148.385 \pm 8.099)$ and Social Sciences Teaching Department scores $(145.897 \pm 12.608)$ were higher than the other departments. As for Lifelong Learning Tendency scores, Social Sciences Teaching scores (132.759 \pm 7.619$)$ and Psychological Guidance and Counseling section scores $(131.231 \pm 6.166)$ were higher than the other branches.

For the "Techno-pedagogical Education Competency" some research displayed significant differences in terms of the branch variable (Polat, 2018) while some researchers found 
significant differences among departments like Kaya et all. (2011); Gömleksiz, Fidan (2011); Şad, Açıkgül, and Delican (2015) and Yalçın İncik and Akay (2017). Interestingly, the highest score for this competency in general belonged to Psychological Guidance and Counselling and the lowest score to Mathematics Teaching contrary to the expectation that students in numeric departments would have more scores than the ones in social departments. There are findings uncovering similar results and exhibiting significant differences in terms of their departments which are related to life-long learning tendencies of teacher candidates (Ayaz, 2016; Evin Gencel, 2013; Arcagök and Şahin, 2014; Şahin, Akbaşlı and Yanpar Yelken, 2010).

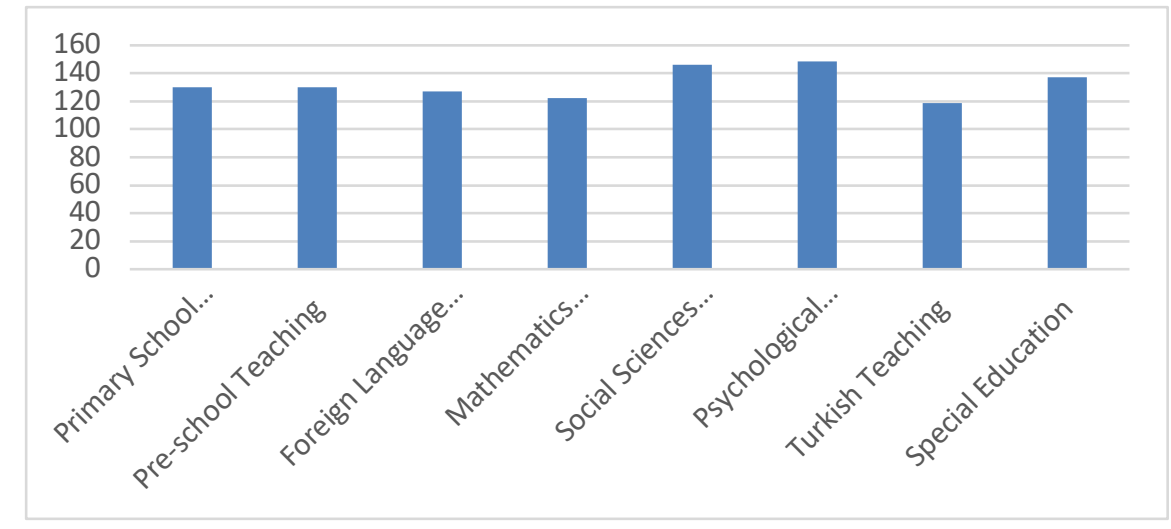

Figure 4.1. Perceived "Techno-pedagogical Education Competency" levels of the teacher candidates.

Perceived "Techno-pedagogical Education Competency" levels of the teacher candidates given in Figure 4.1 and Table 3.6 show that students in some departments such as Mathematics and Turkish Teaching have less perceived "Techno-pedagogical Education Competency" compared to the Psychological Guidance and Counselling students, however most of them are in similar ranges. The reason of this should be enlightened with further qualitative and in-depth research.

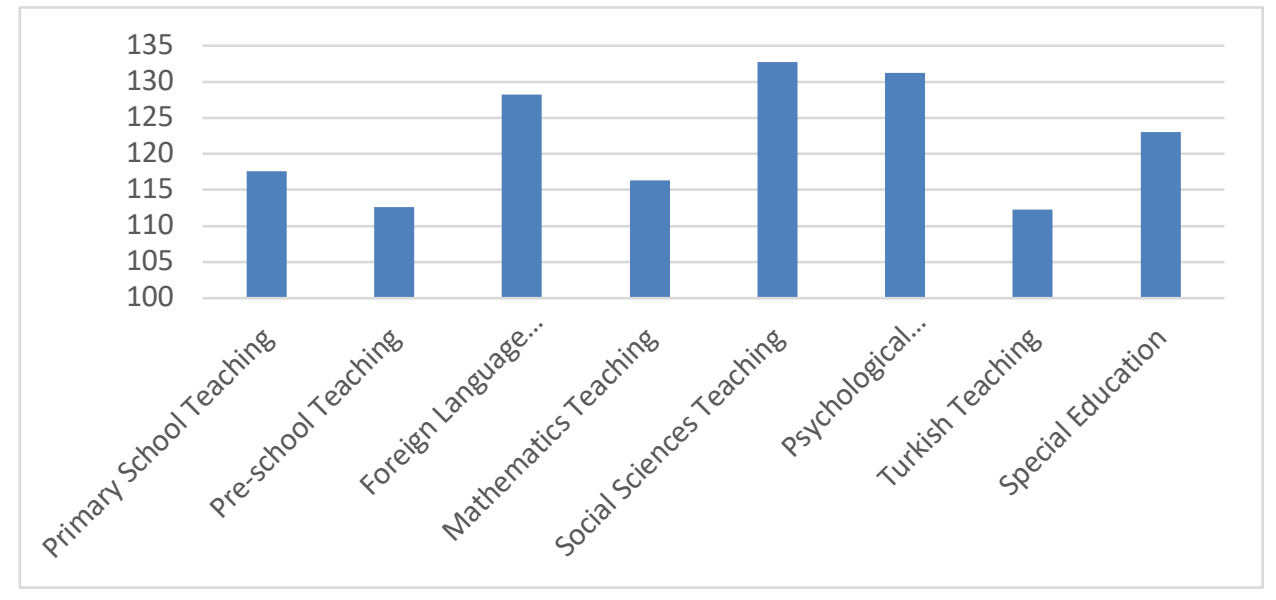

Figure 4.2. Perceived "Lifelong Learning Tendency" of Teacher Candidates

In terms of lifelong learning tendency, the highest score belongs to Psychological Guidance and Counselling and the lowest score belongs to Pre-school Teaching and Turkish Teaching. This can be explained by the fact that Psychological Guidance and Counselling department 
learners encounter and deal with concepts related with life-long learning skills more often than those from other disciplines. Perceived "Lifelong Learning Tendency" levels of the teacher candidates given in Figure 4.2 and Table 3.6 show that students in Turkish Teaching department have less perceived "Lifelong Learning Tendency" whereas Foreign Language prospective teachers, Social Sciences teacher candidates, Special Education teacher candidates and Social Sciences teacher candidates, Psychological Guidance and Counselling, Primary School students have higher values. The reason(s) for that should be enlightened with further qualitative and in-depth research in the future.

In this study it is found that there is a moderate correlation between Techno pedagogical Education Competency and Lifelong Learning Tendency. Özdamlı and Özdam (2014) found that there was a relation between the perception competence of life-time learning approach and abilities in using information-communication technologies of the teachers. Lifelong learning tendency also has a moderate correlation with the sub-dimensions as exertion, ethics and proficiency and design dimensions. It then can be concluded that there is a moderate correlation between perceived techno pedagogical education competency and perceived lifelong learning tendency of teacher candidates. Due to the fact that a limited number of studies are found in the literature concentrating upon this issue, the findings of this research should be handled with caution. This result allows us to infer that students' life-long teaching tendencies are influenced by techno pedagogical Education Competencies to a certain extent.

\section{Recommendations}

In order to grasp the main causes of the significant differences and correlations pertaining to the concepts mentioned above, qualitative studies like in-depth interviews or semiexperimental designs can be referred to in future studies. Furthermore, Techno pedagogical Education Competency and Life-Long Learning Tendency can be investigated with different demographic variables as well as varying competencies and skills. Similar research can be carried out with different samples using different measurement tools to spot any similarities and/or differences with reference to the findings of this research.

\section{References}

Akgün, F. (2013). Pre-service teachers' web pedagogical content knowledge and relationship between teachers' perception of self-efficacy. Trakya University Journal of Education $3(1), 48-58$.

Akpinar, Y. (2003). The impact of higher education on the use of new information technologies by teachers: the case of İstanbul schools. The Turkish Online Journal of Educational Technology-TOJET. 2 (2), 79-96.

Arcagök, S. \& Şahin, Ç (2014). Examination of the teachers' lifelong learning competences levels in terms of some variables. Adlyaman University Journal of the Institute of Social Sciences (16), 394-417.

Arulampalam, W., Booth, A. L., \& Bryan, M. L. (2004). Training in Europe. Journal of the European Economic Association, 2(2-3), 346:60.

Ayaz, C. (2016). The analysis of Lifelong learning tendencies of teachers in terms of some veriables. Unpublished Master Thesis. Bartın University Institute of Educational Sciences, Bartın.

Bilir, M. (2006). Lifelong learning as a requirement of professional development. F. Sayilan and A. Yildiz (Publication), Lifelong Learning: Symposium Proceedings and Discussions (s. 152-162). Ankara: Pegem A Publising. 
Chai, C.S., Koh, J. H., \& Tsai, C. (2011). Exploring the factor structure of the constructs of technological, pedagogical, content knowledge (TPAC). The Asia-Pacific Education Researcher, 20(3), 595-603.

Chang,D-F. Wu, M-L. Lin, S-P. (2012). Adults Engaged in Lifelong Learning: Analysis by Gender and Socioeconomic Status, Australian Journal of Adult Learning, 52(2), 310336.

Chłoń-Domińczak, A. Lis, M. (2013). Does Gender Matter For Lifelong Learning Activity?, Neujobs Working Paper. Institute for Structural Research (IBS)

Cresswell, JW. \& Plano Clark, VL. (2011). Designing and conducting mixed method research. 2nd Sage; Thousand Oaks, CA.

Coşkun, D. Y. (2009). Investigation of Lifelong learning tendency of undergraduate students? in terms of some variables. Unpublished doctoral dissertation. Hacettepe University, Ankara.

Demirel, M. \& Akkoyunlu, B. (2010). Pre-service teachers' lifelong learning tendencies and information literacy self-efficacy perceptions. 10th International Educational Technology Conference, Boğaziçi University, İstanbul.

Evin Gencel, G. (2013). Prospective teachers' perceptions towards lifelong learning competencies. Education and Science. 38 (170), 237-252.

Gömleksiz, M. N. \& Fidan, E. K. (2011). Self-efficacy perception levels of prospective teachers' enrolled at pedagogical formation course toward web pedagogical content knowledge. Turkish Studies International Periodical for the Languages, Literature and History of Turkish or Turkic, 6(4), 593-620.

Gunawardena, C, Rasanayagam, Y, Leitan, T, Bulumulle, K, \& Dort A A-V (2006). 'Quantitative and qualitative dimensions of gender equity in Sri Lankan higher education', Women's Studies International Forum, 29, 562-571.

Gündoğan, N. (2003). "Lifelong learning" as a tool of employment policy in the EU member states and some sample programs and practices. Journal of Public-Labor Law and Economics. 7(2), 1-14.

Gregg, J.P. (1996). Psychological implications and personal perceptions of lifelong learning adults in life satisfaction and self-esteem. Unpublished doctoral dissertation, Wayne University, USA.

Horzum, M. B. (2011). Adaptation of web pedagogical content knowledge survey to Turkish. Elementary Education Online, 10 (1), 257-272.

Jang, S., \& Tsai, M. (2012). Exploring the TPACK of Taiwanese elementary mathematics and science teachers with respect to use of interactive whiteboards. Computers \& Education, 59(2), 327-338.

Johnson, B., \& Christensen, L. (2014). Educational research (quantitative, qualitative and mixed approaches). (S. B. Demir, Çev.). Ankara: The train Book.

İşigüzel, B. (2014). Determınıng the level of proficiency in Techno-pedagogical knowledge competencies of pre-service German teachers. Journal of International Social Research, 7(34), 768-778.

İzci, E., \& Koç, S. (2012). The evaluation of the teacher candidates' views on the Lifelong learning. Adyyaman University Journal of Institute of Social Sciences, 5(9). 101-114.

Kabakcı Yurdakul, I., Odabaşı, H. F., Kılıçer, K., Çoklar, A. N., Birinci, G., \& Kurt, A. A. (2012). The development, validity and reliability of TPACK-deep: A technological pedagogical content knowledge scale. Computers \& Education, 58 (3), 964-977. doi:10.1016/j.compedu.2011.10.012

Karasar, N. (2009). Scientific research method. Ankara: Nobel Publishing.

Kaya, Z., Özdemir, T. Y., Emre, G., \& Kaya, O. N. (2011). Determination of technological pedagogical content knowledge self-efficacy levels of information technology teacher 
candidates. Paper presented at the International Computer \& Instructional Technologies Symposium, Firat University, Elazığ, Turkey.

Kazu, İ. Y. \& Erten, P. (2011). The views of elementary pre-service teachers towards web pedagogical content knowledge. 10th National Elementary Teaching Education Symposium. Cumhuriyet University, Sivas, Turkey.

Koh, J.H.L. \& Chai, C.S. (2011). Modeling pre-service teachers' technological pedagogical content knowledge (TPACK) perceptions: The influence of demographic factors and TPACK constructs. In G. Williams, P. Statham, N. Brown, B. Cleland (Eds.), Changing Demands, Changing Directions. Proceedings ascilite Hobart 2011. (pp.735746).

Mulenga, D. \& Liang, J-S (2008). 'Motivations for older adult's participation in distance education: A study at the National Open University of Taiwan', International Journal of Lifelong Education, 27(3), 289-314.

Murat, A. (2013). The opinions of the science preservise teachers on the effects of the Technopedagogical knowledge competencies on ICT usage, Unpublished Master's Thesis, https://tez.yok.gov.tr/, Date of access: 09.09.19

Murat, A. Erten, H. (2018). The use of information and communication technologies of science teacher candidates and their opinions about integration of these technologies in learning- teaching process, Firat University, Journal of Social Sciences, 28 (1) 6171

Özdaml, F. \& Özdam, H. (2014). Life-long Learning Competence Perceptions of the Teachers and Abilities in Using Information-Communication Technologies, Procedia - Social and Behavioral Sciences 182 ( 2015 ) 718 - 725

Palinkas, L. A., Horwitz, S. M., Green, C. A., Wisdom, J. P., Duan, N., \& Hoagwood, K. (2015). Purposeful Sampling for Qualitative Data Collection and Analysis in Mixed Method Implementation Research. Administration and policy in mental health, 42(5), 533-544. doi:10.1007/s10488-013-0528-y

Patton MQ. (2002). Qualitative research and evaluation methods. 3rd Sage Publications; Thousand Oaks, CA

Polat, T. (2018). Examining Technopedagogical knowledge competencies of foreign language teachers in Turkey, Unpublished Master's Thesis, https://tez.yok.gov.tr/, retrieved from 09.09.19

Quintini, G. (2011). Over-Qualified or Under- Skilled. A review of existing literature. OECD Social, Employment and Migration Working Papers, (121). doi:.http://dx.doi.org/10.1787/5kg58j9d7b6d-en

Shulman, L.S. (1986). Those who understand: knowledge growth in teaching. Educational Researcher, 15(2), 4-14

Suri, H. (2011). Purposeful Sampling in Qualitative Research Synthesis, Qualitative Research Journal, vol. 11, no. 2, pp. 63-75. DOI 10.3316/QRJ1102063. This is a peer-reviewed article

Şad, S. N. Açıkgül, K. \& Delican, K. (2015). Senior preservice teachers' senses of efficacy on their technological pedagogical content knowledge (TPACK), Journal of Theoretical Educational Science, 8(2), 204-235

Şahin, M., Akbaşl1, S., \& Yanpar, T.Y. (2010). Key competences for lifelong learning: the case of prospective teachers. Educational Research and Reviev. 5(10), 545-556.

Şimşek, Ö., Demir, S., Bağçeci, B., \& Kınay, İ. (2013). Examining Technopedagogical knowledge competencies of teacher trainers in terms of some variables. Ege Journal of Education, 14(1), 1-23

Tabachnick, B.G., \& Fidell, L.S. (2007). Using multivariate statistics, Fifth Edition. Boston: Pearson Education, Inc 
Tinio, V. (2003). ICT in education. ICT for Development, United Nations Development Programme, New York.

Ünal Bozcan, E. (2010). Use of technology in educational activities. Educational Technology Journal of Research, 1(4), http://www.acarindex.com/dosyalar/makale/acarindex1423877260.pdf,ate Date of access: 09.09.19

Yalçın İncik, E. \& Akay, C. (2017). A Comprehensive Analysis on Technopedagogical Education Competency and Technology Perception of Pre-service Teachers: Relation, Levels and Views, Contemporary Educational Technology, 8(3), 232-248

World Bank (2005). World development report 2006: Equity and development, New York: Oxford University Press.

World Bank (2007). 2007 world development indicators, Washington, DC, World Bank. 